\title{
Investigation of the Relationship between Parents' Awareness of Digital Parenting and the Effects of Digital Games on Their Children
}

Sümeyra Akkaya, Inonu University, Faculty of Education, 0000-0002-9942-9848

Zeynep TAN(Master Student), Inonu University, Institute of Educational Sciences 0000-0002-

2520-4646

Metin KAPIDERE, Inonu University, Faculty of Education, 0000-0002-0039-0710

Seda ŞAHIN, Inonu University, Faculty of Education, 0000-0002-4034-7864

\begin{abstract}
With the changing living conditions and developing technology, digital parenting has become a noteworthy concept. Opening their eyes in a digital world, children have started to meet their needs such as games with digital games. The aim of this study is to examine parents' digital awareness levels and their views on the effects of digital games at an early age in terms of demographic variables. The quantitative research method was adopted in the study, and the model of the research is the factorial pattern, one of the multivariate designs that aims to reveal the effects of multiple independent variables together. The research group consists of 523 parents selected from the parents of children between the ages of 3-8, using the random sampling method. MANOVA was applied for nine dependent variables and five independent variables in the study. Result of the research, the digital awareness levels of parents differ only in the risk protection sub-dimension according to the number of children parents have. The digital awareness levels of parents differ only in the risk protection sub-dimension according to the number of children parents have. The digital awareness levels of parents differ significantly in the sub-dimensions of protection from risks, efficient use and digital neglect according to the independent variable of the type of game their children prefer to play. Parental awareness levels regarding the effects of digital games on their children at an early age show a significant difference according to the independent variables of the age when children start playing digital games and the type of game their children prefer to play. Parental awareness levels about the effects of digital games on their children at early ages differ significantly only in the social sub-dimension according to the age when children start playing digital games. Parental awareness levels regarding the effects of digital games on their children at an early age differ significantly according to the independent variable of the type of game their children prefer to play, with fun, physical, social and emotional sub-dimensions.
\end{abstract}

Keywords: digital parenting, digital games, early childhood Suggested Citation

İnönü University Journal of the Faculty of Education

Vol 22, No 1, 2021

pp. 889-917

DOI:

10.17679/inuefd.905569

Article type:

Research article
Received : 29.03.2021

Accepted : 21.05.2021

Akkaya, S., Tan, Z., Kapıdere, M. \& Şahin. S. (2021). Investigation of the relationship between parents' awareness of digital parenting and the effects of digital games on their children, Inonu University Journal of the Faculty of Education, 22(1), 889-917. DOI: 10.17679/inuefd.905569 


\section{INTRODUCTION}

In the age that we live in, technology develops day by day, making life and access to information easier. However, it also changes social habits. With this changing and development, people allow a large part of their time to use the internet. With the widespread use of the Internet, it has been invented till today and by its nature, it has begun to change all entertainment and communication ways, traditional institutions, social life, perceptions of reality, and people's relations with each other and with the world. (Başaran Özdemir \& Babacan, 2011).

The digital world shows its presence in all areas of life and is actively used due to the practicality it provides. Especially during the pandemic period, people's closure at home adversely affects social life and urges people to get in further into the digital environment. In addition to the basic physiological needs of human beings, they also need to have fun, interact with other people and satisfy their thirst for knowledge. The digital environment can eliminate all of these when viewed from the outside, but this virtual world is starting to separate people from real life more and more.

Today, technology shows its presence in the lives of people of all age groups, specifically children and young people who use technology widely (Yiğit \& Günüç, 2020). One of the areas of technology that develops day by day, adding new ones on top of the old ones and making daily life easier, is information technologies. The use of technological tools and the internet is increasing day by day. Tools such as phones, computers, tablets, and the internet, which are now easily accessible by almost everyone, are the tools actively used by adults in business life, youth and children in education life, and people of all ages in social life. With the ease of access and common use of these tools, the age of internet usage is decreasing day by day (Orman \& Arıcak, 2019). Turkey Statistical Institute (TUIK, 2020) households use information technology in 2019 according to the survey results, while $73.3 \%$ of the $16-74$ age 
group, Internet usage for individuals was $79.0 \%$ in 2020 . Again, the results of the same research show that while the opportunity to access the internet from home was $88.3 \%$ in 2019 , this rate increased to $90.7 \%$ in 2020 . Due to the Covid-19 pandemic in 2020, the use of digital tools and the internet has become essential in communication, education, and many business sectors, and naturally, the number of users has increased. In this period, children who are closed to home continue their education from home and use the digital environment intensively. Children who stay away from their social environment can turn to digital games to meet their entertainment and socialization needs.

Children spend most of their time outside of their physiological needs by playing games, and they can express their emotions by imitating the events they experience in daily life. Although the main purpose of the game, willingness, and entertainment have not changed from the past to the present, the tools used in the game have started to change with the digital change in the world (M. Hazar et al., 2016). Along with the rapidly developing game industry in the '90s, digital games that were swiftly consumed and new ones were released day by day emerged (Yalçın Irmak \& Erdoğan, 2016). The game activity, which started with people imitating natural events in the past, has now started to leave its place to digital games (Z.Hazar \& Hazar, 2017). Games also took their share from the innovations brought by the digitalizing world, and children started to spend most of their time with digital games (Söğüt, 2020). Playing is one of the crucial activities that the child does in daily life, voluntarily, with or without purpose, and that contributes to his / her development. Play is an activity that enables children to perceive the world they live in through their own experiences and contribute significantly to their development (Aksoy \& Dere Çiftçi, 2020). Often, the unsafe streets, insufficient space for children, and lack of time cause parents to direct their children to the digital environment (Işıkoğlu Erdoğan, 2019). The visual richness offered by digital tools attracts the attention of preschool children. Due to the joy and pleasure of playing digital games, children prefer these games a lot (Aydoğdu Karaaslan, 2015). In traditional games, it is 
aimed to reach the goal by overcoming some obstacles. In digital games, these actions take place in a digital environment (Söğüt, 2020). Thanks to the game, children explore their surroundings, learn objects and concepts, and develop problem-solving skills (Aktaş Arnas, 2017). As with traditional games, digital games also contribute positively to the mental development of children. Since preschool children are in the concrete operational period, they can comprehend abstract mathematical information in concrete form thanks to digital games. Likewise, language skills, mental skills, and memory development are also supported by digital games (Schacter \& Jo, 2016). Besides, digital games contribute to hand-eye coordination, an increase of self-confidence, feelings such as curiosity, fun, and challenge, increasing the desire to learn, being equipped with the latest technology, and being an effective user. Also, it contributes to basic reading skills, basic mathematical skills, language skills, and social skills (Griffiths, 2002). It should not be overlooked that digital games that are used correctly and consciously can be educational and encourage children to think and learn more (Griffiths, 2003). Thanks to educational digital games, behavioral changes can be created in students and positive behaviors can be reinforced (Prot et al., 2014). As tools such as mobile phones and tablets are being used more and more in the field of education, more effective and fun learning is realized thanks to concept teaching mathematics teaching digital games to preschool children (Genç Çopur et al., 2020). Although digital games are a fun activity for children, many adverse effects can be seen when excessively and unconsciously used. Due to the dramatically growing game industry, examining game contents has become difficult, and children in the developmental stage have become a threat from various aspects (Taylan et al., 2017). According to the study of Toran et al. (2016), it is seen that children are influenced by their social environment and take adults as role models in their use of technology. Besides, it has been observed that the age of children to start playing digital games is around 3 years old. Considering the developmental characteristics of children in this period, it is a fact that consciously used digital games can positively contribute to the development of the child, and it 
should not be ignored that digital games offered to children uncontrolled and without any restrictions may negatively affect the cognitive, emotional, social and physical development of the child. Digital games affect children who are in the developmental period physically, emotionally, cognitively, and socially. In the study of Mustafaoglu and Yasacı (2018), it was determined that digital games lead to mental problems such as gameplay addiction, anxiety disorder, aggression, depression, and social disorders. Due to spending too much time in front of digital games, physical problems such as shoulder, spine, wrist pain, eye health deterioration, and sleep disturbance occur. When the sociological and psychological effects of digital games are analyzed, it has seen that loneliness, tendency to violence, thinking of being socialized in the digital environment, and emotional inadequacies (Ataman Yengin, 2019). These games are known to isolate children, isolate them from life, and cut them off from real life (Z. Hazar \& Hazar, 2017). Today, the fact that most households have internet networks and almost everyone uses technological tools provides an environment for children to play the game they want comfortably whenever and wherever they want (Cengiz Saltuk \& Erciyes, 2020). Due to the excessive time wasting on digital games, children neglect their responsibilities and lessons, which brings academic failure either (Torun et al., 2013). Besides, the fact that children playing digital games are inactive in front of the screen for hours is a negative situation in terms of physical health. While traditional games provide many physical and social benefits to children; digital games have been the target of criticism for restricting movement and social life (Torun et al., 2013). Considering the developmental characteristics of preschool children, traditional games, in which physical activity is high, players can adapt the games to themselves, and interpersonal communication is intense, meet the movement needs of children more. In digital games, staying in a fixed position for hours and playing alone for the child most of the time have negative physical and social effects (Z. Hazar et al., 2017). Another negative effect of digital games is game addiction. Digital game addiction, which adversely affects the development of children, is a major threat, but there are negations such 
as spending inefficient time for children, not fulfilling their responsibilities, identifying themselves with the characters in the game, and overreacting in case of intervention (Taylan et al., 2017). The success achieved by children in games, the sense of satisfaction provided by this success, the opportunity to meet with other digital players in different places and cities, the immersion in the game, the uncertainty of the next step, self-play character identification, avoidance of facts are some of the components of children being addicted to digital games (Yee, 2006).

Although digital games that change and virtualize the children's world have functions such as leisure time and stress relief, violence is perceived as a normal thing by children due to the violent elements involved (Aydoğdu Karaaslan, 2015). Due to malware and violent games, children are psychologically negatively affected and their tendency to violence increases. Especially recently developed digital games offer the user the opportunity to create their character. Thanks to this situation, children can identify with the character they have created, integrate violence into their life, and begin to live in the virtual world by breaking away from real life. Parents have important responsibilities at this point. Family is the building block of society and every parent is the child's first teacher. Technology has also taken its place in family life, making almost all family members active users. The fact that a large portion of time is wasted with playing games that are not suitable for the age of children and parents worry about its gradually turning into addiction (Torun et al., 2013). The most important duty of parents is to protect the health of their children, to ensure their safety, and to reintegrate them into society (Söğüt, 2020). Following the developments in the digital environment, being able to use the internet and being a role model for their children in terms of internet use were added to the responsibilities of parents who are responsible for protecting and looking out for their children (Yaman et al., 2016). It is of great importance for parents to analyze the games their children play and to know whether they are suitable for the level of their children (Genç Çopur et al., 2020). The fact that today's families become digital citizens requires their children 
to be ready and equipped to protect them from the negative effects of the internet. Today, it is not the correct to resist technology and innovation, it is critical to use technology and the internet consciously. Parents should guide their children instead of restricting their use of technology, and raise awareness of their children about the benefits and harms of the internet (Zeybekoğlu Akbaş \& Dursun, 2020). According to the research conducted by Yiğit and Günüç (2020), families are categorized as families whose children are addicted to digital games, whose children are not addicted to digital games, and who are in the risk group. According to the study, it was concluded that parents whose children are addicted to digital games could not communicate properly with their children. They did not pay enough attention to them and they went through some problems in the family, and thus were committed to violence occasionally. Parents' excessive oppressive attitudes and communication disorders push children into the digital environment even more. Parents need to inform their children about digital games based on healthy communication, make the necessary limitations and guide their children to be selective about digital games. First of all, this requires parents to be conscious of this issue. In the study conducted by Erboy and Akar Vural (2010), it was concluded that children with a lower level of mothers' education are more addicted to digital games than children with high maternal education levels. Today, being a good digital citizen and a digital parent has become essential. Digital literacy is necessary equipment for individuals to be successful in the digital age and to be equipped for future developments (Terkan \& Taylan, 2010). It does not seem possible to live in isolation from the digital world and to give up the conveniences it provides. Instead of this, it is necessary to use technology and the internet, which occupy a larger place in human life, correctly and consciously. In particular, a new one has been added to the duties of the parents of children born into the digital world. It is one of the most up-to-date and important duties of digital parents not to ignore the benefits of digital games, which children frequently and zealously use, to be aware of the harms, and to raise awareness and guide children in this regard. It would be more accurate to focus on the 
relationship between digital games and learning, rather than seeing them as a factor of violence and addiction (Sezen, 2011).

\section{Purpose of The Study}

The purpose of this study is to examine parents' digital awareness levels and their views on the impact of digital games in early ages in terms of demographic variables. In this direction, answers were sought for the following two basic sub-problems and their sub-problem situations;

1. The sub-dimensions of Protection From Risks (PR), Efficient Use (EU), Negative Modeling (NM) and Digital Neglect (DN) expressing the digital awareness of parents;

a. Does it differ significantly from to the gender of the parents?

b. Does it differ significantly from to the number of children parents have?

c. Does it differ significantly from to the average number of hours per day spent by parents with digital games?

d. Does it differ significantly from to the child's starting age of using digital tools?

e. Does it differ significantly from to the type of game the child prefers to play?

2. Entertainment, Learning, Physical, Social and Emotional sub-dimensions considered as the effect of digital games in early ages;

a. Does it differ significantly from to the gender of the parents?

b. Does it differ significantly from to the number of children parents have?

c. Does it differ significantly from to the average number of hours per day spent by parents with digital games?

d. Does it differ significantly from to the child's starting age of using digital tools?

e. Does it differ significantly from to the type of game the child prefers to play? 


\section{METHOD}

This study was carried out by quantitative research method. The design of this current study is factorial design which is one of the multivariate designs that aims to reveal the effects of multiple independent variables together (Başol, 2008). When a research study has two or more independent variables which are referred to as factors, it is known as factorial design (Field, 2009). This study is an independent factorial design, because the independent variables are consisted of independent sub groups.

In this study, the independent factorial design, in which the differences in the parents' digital awareness levels and the perceptions of the effects of digital games were analyzed via the independent variables of gender, number of children, average digital media use, age to start using digital game play and the type of game prefered, was adopted.

\section{Participants of the Study}

The participants of the study are 523 parents. For the research group, parents who have children between the ages of three and eight attending any educational institutions in the 2020-2021 academic year were reached. The participants of the study were determined via ramdom sampling.

Power analysis test was conducted to test the suitability of the number of data in the research group for the required analysis method. In the analysis done with the Gpower 3.1 program, the $15 \%$ effect size, $5 \%$ error amount and $95 \%$ power were considered. In the study, the minimum sample size that can give a $95 \%$ power analysis result was calculated as 450 for the MANOVA analysis conducted for nine dependent and five independent variables. Since the number of the participants in the current study is 523 , it has been observed that the sampling size in the this study is sufficient. 
The distribution of the research group according to the categories of the relevant independent variables is given in the Table 1

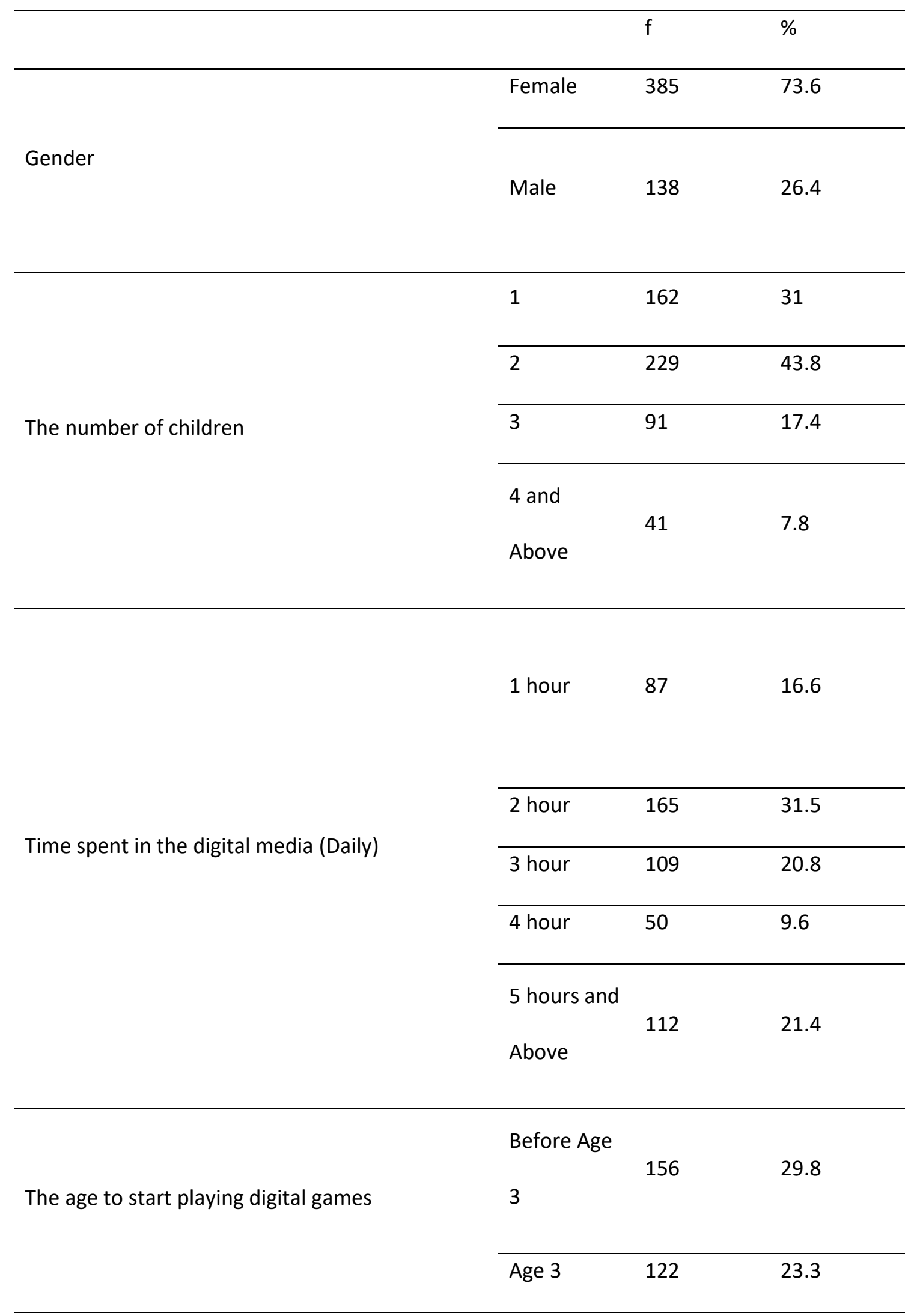




\begin{tabular}{|c|c|c|c|}
\hline & Age 4 & 100 & 19.1 \\
\hline & Age 5 & 60 & 11.5 \\
\hline & $\begin{array}{l}\text { Age } 6 \text { and } \\
\text { older }\end{array}$ & 85 & 16.3 \\
\hline \multirow{3}{*}{ The type of game prefered } & Traditional & 280 & 53.5 \\
\hline & & & \\
\hline & Digital & 243 & 46.5 \\
\hline
\end{tabular}

As can be seen in Table 1, approximately $74 \%$ of the participating parents are female and $25 \%$ are male. The ratio of families with one child is $31 \%$, with two children is about $44 \%$, with three children is about $17 \%$, and of families with four children or more is about $8 \%$.

It is seen that more than half of the participants have one or two children.

For the daily time spent in the digital environment, the rate of those who spend one hour is approximately $17 \%$, two hours $32 \%$, three hours approximately $21 \%$, four hours approximately $10 \%$ and 5 hours and above $21 \%$. It is observed that approximately $50 \%$ of the group spends three hours or more per day in the digital environment. When the data is checked considering at which age digital game play starts to be used, it is seen that approximately $30 \%$ of the parents in the group expose their children to digital game play at the age of three and before. Approximately $23 \%$ of the parents introduce digital game play to their children when they are three years old, and $19 \%$ of them do that when their children are four-years-old while approximately $12 \%$ of the parents introduce their five years old children to digital game play and $26 \%$ of the parents do that when their children are six years and older. It was observed that $72 \%$ of the participants introduced their children to digital game play before the age of 4 . $54 \%$ of the parents stated that their children preferred traditional games, while $46 \%$ stated that their children preferred digital games. 


\section{Data Collection Instruments}

Digital Parenting Awareness Scale and The Scale of the Effects of Digital Games at Early Years were used in the study.

\section{Digital Parenting Awareness Scale (DPAS)}

The Digital Parenting Awareness Scale consists of 16 items. The scale has four sub-factors. These are Protection From Risks (PFR, 4 items); Efficient Use (EU, 4 items); Being a Negative Model (BNM; 4 items) and Digital Neglect (DN, 4 items). Parents were asked to indicate how often they encountered each statement with a Likert-type rating. Reactions to the items were graded as $1=$ Never, $2=$ Rarely, $3=$ Sometimes, $4=$ Frequently, $5=$ Always. The sub-factors of DPAS were evaluated independently from each other. The scores that can be obtained from the sub-factors range between 4 and 20. The high scores on the Protection From Risks and Efficient Use sub-dimensions indicate that digital parenting awareness is high while the high scores on Being a Negative Model and Digital Neglect sub-factors indicate that digital parenting awareness is low. The cronbach alpha internal consistency coefficients were .799 for the BNM sub-dimension; .785 for the DN sub-dimension; It is seen that EU sub-dimension takes .717 and PFR sub-dimension .634.information for sub-factors(Manap\& Durmuş,2020).

\section{The Scale of the Effects of Digital Games at Early Years}

The KMO value was found .90 after the validity and reliability analysis. The total variance explained is $63.40 \%$. The factor load values of the scale, which turned out to be composed of 5 factors, vary between .87 and .54 . As a result of the reliability analysis, it was determined that the internal consistency coefficient of the total scale was .91. Internal consistency coefficients of the factors are .82 for fun dimension, .90 for learning, .86 for physical, .87 for social, and .84 for emotional dimension. The analyses conducted have shown that the "Scale of the Effects of Digital Games at Early Years", which consists of 25 items, is a valid and reliable scale. 
Cronbach Alpha coefficients were calculated to test the reliability of the sub-factors of the instruments in the study group(Balaban Dağal \& Bayindir, 2019). Alpha index results are in Table 2.

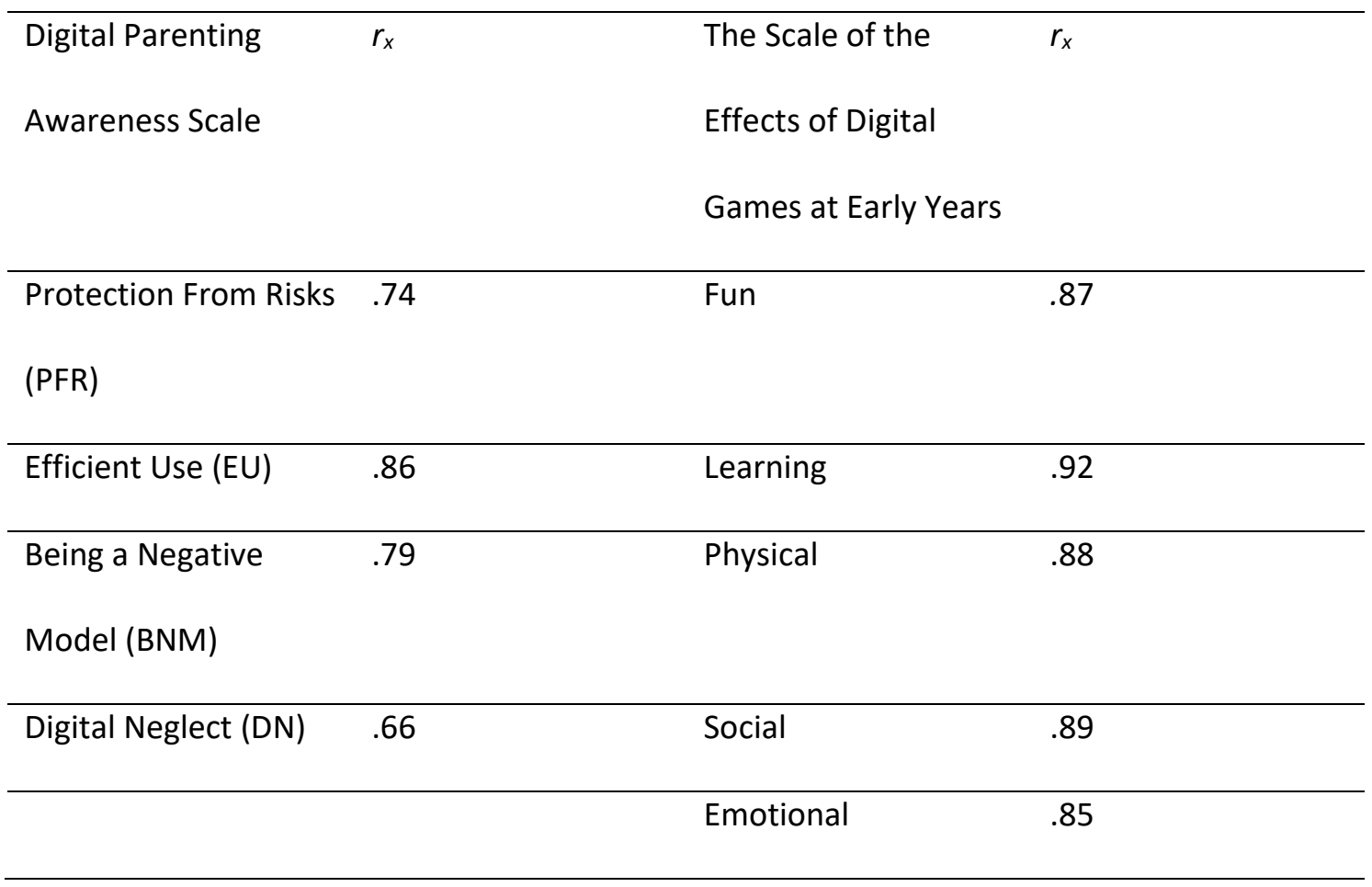

As seen in Table 2, it is observed that the Digital Parenting Awareness Scale ranged from .65 to .86 for sub-factors, and between .85 and .92 for the sub-factors of Digital Games in Early Years. Cortina (1993) stated that if the number of items is 12 or above and the correlation between items has a sufficiently high correlation $(>.50)$, it is acceptable for the alpha value to be around .70 or below (range .65-.84). In this case, when the correlation coefficient between items for the DN sub-dimension was examined, it was observed that the correlation coefficient between the three items was .50 and above. Therefore, it has been proven that the tools used in the study are reliable in the applied group.

\section{Data Analysis}

Protection from Risks (PFR), Efficient Use (EU), Being a Negative Model (BNM) and Digital Neglect (DN), which express the digital awareness of parents and Fun, Learning, Physical, Social and Emotional sub-dimensions, which are considered as the effects of digital 
games in the early ages, are dependent variables. Additonaly, gender, the number of children owned, the daily time spent using digital media, the age of meeting with digital game play, and the type of game prefered to play are the independent variables of the study. Factorial MANOVA, one of the multivariate analyses, was used, because there are more than one dependent variable and more than two independent variables in the study. With this analysis, it is aimed to evaluate more than one dependent variable together as well as to reveal which factor is more important. The advantage of MANOVA to univariate analyses is that it not only tests the difference between groups but also reveals the effect of the relationship between dependent variables, which means, MANOVA explains how group members are distributed according to each dependent variable, as well (Alpar, 2003; Field, 2009; Huberty \& Morris, 1989).

Before starting the basic data analysis, the data navigation was processed, and the assumptions required for MANOVA were tested. It was observed that there was no missing value in the research data as a result of the missing values analysis. For the extreme value, $\mathrm{Z}$ values were calculated and it was checked whether there was any data outside the range of $[+3,-3]$. It was observed that in the $Z$ values calculated for all dependent variables, there were data outside this range for the PFR, EU, BNM and DN sub-factors. However, before deleting the extreme value, the normality test was performed.

Kolmogrov Smirnov test was conducted for the normality test. After the Kolmogorov Smirnov test, it was found that PFR (PFR $\mathrm{KKS}=.12, \mathrm{p}<.05), \mathrm{EU}\left(\mathrm{EU}_{\mathrm{KS}}=.12, \mathrm{p}<.05\right), \mathrm{BNM}\left(\mathrm{BNM}_{\mathrm{KS}}=.11, \mathrm{p}<\right.$. $, \mathrm{p}<.05)$, and Fun $\left(\mathrm{F}_{\mathrm{KS}}=.17, \mathrm{p}<.05\right)$, Learning $\left(\mathrm{L}_{\mathrm{kS}}=.06, \mathrm{p}<.05\right)$, Physical $\left(\mathrm{P}_{\mathrm{KS}}=.11, \mathrm{p}<. .09, \mathrm{p}\right.$ $<.05)$ and Emotional $\left(E_{k s}=.17, p<.05\right)$ variables did not show normal distribution. Nonetheless, when the coefficients of skewness of the variables were examined $(.50, .46,-.47,-.59,-.13, .64$, .09 and .67 , respectively), it was observed that the distribution was close to normal. Thus, no data was deleted from the data group. 
For the assumptions required for MANOVA, firstly, the relationship between dependent variables was examined. Since one of the aims of MANOVA reveals the effect of the relationship between dependent variables, a moderate relationship is expected between dependent variables (Huberty \& Morris, 1989). Ramsey (1982) stated that as the relationship between dependent variables increases, the power of MANOVA decreases (cited in Field, 2009). Therefore, Tabachnick and Fidell (2007) stated that high negative correlation or acceptable moderate level correlation gives the best MANOVA result for the relationship between dependent variables. As a result of the correlation analysis, it was seen that the correlation coefficients between the PFR, EU, BNM and DN sub-factors varied between .29 and .40 , which indicated a moderate relationship. It was revealed that there was a relationship between the Fun, Learning, Physical, Social and Emotional factors ranging from .34 to .66 . In order to test another assumption which was the multiple normality assumption, Mahalanobis distance values were calculated (Pallant, 2005; Tabachnick \& Fidel, 2007). If the Mahalanobis value is less than .001 , which is the significance level, it is expressed as a sign of extreme value (De Maesschalck, Jouan-Rimbaud \& Massart, 2000). Since the significance level of this value calculated for the dependent variables in the study is higher than .001 , the assumption of multiple normality has been provided. Levene test results were examined for the homogeneity of variances. The fact that the $p$ value for the Levene test is greater than .05 indicates that the variance between groups is equal (Field, 2009). Levene test $p$ value calculated in the study was found over .05. Homogeneity of variance-covariance matrices is taken as .001 for the Box's M test (Seçer, 2015). It was observed that the tested Box's M test $p$ value was less than .001 . However, Allen and Bentler (2008) state that if the sample size is 30 and above, the result of the Box's M test can be ignored.

For the distribution between groups, large group $n /$ small group $n<1.5$ criteria were examined. Stevens (1996) states that if the ratio of the group sizes is close to or equal to each other, the effect of the F test on Type I Error is very small. When the relevant criteria were 
examined for the groups, it was concluded that this ratio was higher than 1.5. In this case, while interpreting the results of the MANOVA test, when variance homogeneity is violated, and the sample number is small, and there are unequal groups, the more resistant Pillai's Trace index is interpreted. Pillai's trace is considered one of the strongest statistics ranging from 0 to 1 (Olson, 1974).

\section{FINDINGS}

The results of the research are reported according to two main problem situations and sub-problems. MANOVA results of parents' Digital Awareness levels on the variables of gender, number of children owned, daily time spent using digital media, age of meeting with digital game play, and game type variables

First of all, whether the dependent variables in the study differed between the groups was examined with Pillai's trace value.

Test results are given in Table 3

\begin{tabular}{lllllll}
\hline Group & Pillai's & $F$ & Hypothesis & Error sd & $p$ & $\eta^{2}$ \\
& Trace & & sd & & & \\
& & & & & & \\
\hline Gender & .012 & .946 & 4 & 304 & .437 & .012 \\
\hline Number of & .098 & $\mathbf{2 . 5 8}$ & $\mathbf{1 2}$ & $\mathbf{9 1 8}$ & $.002^{*}$ & .033 \\
Children & & & & & & \\
\hline Duration & .051 & .999 & 16 & 1228 & .455 & .013 \\
\hline Starting age & .073 & 1.43 & 16 & 1228 & .121 & .018 \\
\hline Type of Game & .069 & $\mathbf{5 . 6 1}$ & $\mathbf{4}$ & $\mathbf{3 0 4}$ & $.000 *$ & .069 \\
\hline
\end{tabular}

When Table 3 is analyzed, Gender (Pillai's Trace $=.012 ; \mathrm{F}(4 ; 304)=.946, p>.05)$, time spent in digital environment (Pillai's Trace $=.051 ; F(16 ; 1228)=.999, p>.05)$ and the age of starting to use digital game play (Pillai's Trace $=.073 ; F(16 ; 1228)=1.43, p>.05$ ) variables, while the dependent variables do not differ, the number of children at home (Pillai's Trace $=.098 ; \mathrm{F}$ (12; 
$918)=2.58, p<.05)$ and pleasure type (Pillai's Trace $=.069 ; \mathrm{F}(4 ; 304)=5.61, \mathrm{p}<.05)$ variables differ.

At first, the impact value or felling has been interpreted in order to examine the significance of the interactions. The effect value used to determine the direction of the size of the relationship or difference is a standard scale value that expresses how many standard deviations the group means compared to each other (Başol \& Göçmen, 2005; Koklu, Büyüköztürk \& Bokeoglu, 2007). ฤ2 =.01 "small”, $\eta 2=.06$ "medium level" and an eta squared value of $\eta 2=.14$ and above is interpreted as a "large" effect (Cohen, 1988). Therefore, $3 \%$ of the variants of the scores obtained from the linear component formed for digital awareness sub-dimensions are explained by the number of children owned and $7 \%$ by type of the game prefered. The degrees of difference are small and medium, respectively.

One-way "ANOVA tests (Multivariate ANOVA) were examined" in order to observe the dependent variables contributing to the multivariate difference and the results of the followup analysis are given in Table 4

Table 4

One-factor ANOVA results for the difference between groups of sub-dimensions of parents' Digital Awareness Level

\begin{tabular}{|c|c|c|c|c|c|c|}
\hline Independent & Dependent & $\mathbf{F}$ & $\mathbf{p}$ & Sd & $\eta^{2}$ & Difference \\
\hline Variable & Variable & & & & & \\
\hline \multirow[t]{5}{*}{ Number of Children } & PR & 6,223 & $.000 *$ & \multirow{5}{*}{$3 / 307$} & .057 & 1-4 and older \\
\hline & & & & & & 2- 4 and older \\
\hline & EU & .091 & .965 & & .001 & - \\
\hline & NM & 2.359 & .072 & & .023 & - \\
\hline & DN & 2.544 & .056 & & .024 & - \\
\hline
\end{tabular}




\begin{tabular}{|c|c|c|c|c|c|c|}
\hline \multirow[t]{4}{*}{ Type of Game } & PR & 12.677 & $.000^{*}$ & \multirow{4}{*}{$1 / 307$} & .040 & Traditional-Digital \\
\hline & EU & 56.375 & $.000 *$ & & .155 & Traditional-Digital \\
\hline & NM & 2.423 & .121 & & .008 & - \\
\hline & DN & 14.712 & $.000 *$ & & .046 & Traditional-Digital \\
\hline
\end{tabular}

As can be seen in Table 4, the digital awareness level of the parents differs significantly only from the Risk Protection sub-dimension according to the number of children ( $F 3 / 307=6.223$, $p<.05)$. When looking at the direction of the difference, it was observed that the differentiation was between parents who have four or more children and parents who have one or two children. Parents with four or more children $(X=1.71)$ were found to be lower than parents with one child $(X=2.20)$ and two children $(X=2.06)$ in terms of protection from risks. Approximately $6 \%$ of the digital awareness protection from risks dependent variable is explained by the number of children owned. In other words, it can be said that the effect degree of the number of children in the house is partially low. Efficient use for the number of children variable $(F 1 / 307=.091, p>.05)$, negative modeling $(F 1 / 307=2.359, p>.05)$ and digital neglect $(\mathrm{F} 1 / 307=2.544, \mathrm{p}>.05)$ It has been revealed that there is no significant difference according to the dependent variables.

When the differentiation level of the sub-dimensions for the game type variable is examined, the sub-dimension of being a negative model $(F 3 / 307=2.423, p>.05)$ does not differ significantly. When the variables of protection from risks ( $F 1 / 307=12.677, p<.05)$, efficient use $(F 1 / 307=56.375, p<.05)$ and Digital Neglect $(F 1 / 307=14.712, p<.05)$, the difference is significant. has been seen. In the risk protection variable, it is said that the parents whose children prefer digital games $(X=2.14)$ have higher levels of awareness compared to the parents who prefered traditional games $(X=1.91)$. When the effect size was examined, it was seen that the effect degree was low $(2=.04)$. Considering the efficient use, it has been observed that the parents whose children prefer digital games $(X=2.62)$ have higher levels of 
awareness compared to the parents who prefer traditional games $\left(X^{-}=1.99\right)$. Approximately $16 \%$ of their productive usage levels are explained by the game type that children prefer. It can be said that the prefered game type has a high effect on the efficient use dependent variable. A similar result was found in the comparison made for the digital neglect variable. Parents whose children prefer digital games $(X=3.65)$ have higher awareness than parents who prefer traditional games $(X=3.99)$. However, the effect degree $(2=.05)$ is low.

MANOVA results regarding the effects of digital games in Early Years on the variables of gender, number of children owned, daily time spent with digital media, age of meeting with digital game play and game type variables prefered to play.

Whether the dependent variables differentiate between the groups was examined with the Pillai's trace value in the same way. Test results are given in Table 5 MANOVA results of the effects levels of digital games in the Early Years

\begin{tabular}{lllllll}
\hline Group & Pillai's & $\mathrm{F}$ & Hypothesis & Error & $\mathrm{p}$ & $\eta^{2}$ \\
& Trace & & sd & sd & & \\
\hline Gender & .015 & .940 & 5 & 303 & .455 & .015 \\
\hline Number of & .057 & 1.189 & 15 & 915 & 274 & .019 \\
Children & & & & & & \\
\hline Duration & .059 & .916 & 20 & 1224 & .567 & .015 \\
\hline Starting Age &. $\mathbf{1 2 4}$ & $\mathbf{1 . 9 5 9}$ & $\mathbf{2 0}$ & $\mathbf{1 2 2 4}$ & $.007^{*}$ & $\mathbf{. 0 3 1}$ \\
\hline Type of Game & $\mathbf{. 0 4 2}$ & $\mathbf{2 . 6 8}$ & $\mathbf{5}$ & $\mathbf{3 0 3}$ & $\mathbf{. 0 2 2 *}$ & $\mathbf{. 0 4 2}$ \\
\hline
\end{tabular}

Analyzing the Table 5 Gender (Pillai's Trace $=.015 ; F(5 ; 303)=.940, p>.05$ ), the number of children owned $($ Pillai's Trace $=.057 ; F(15 ; 915)=1.189, p>.05)$ and the time spent in the digital environment $($ Pillai's Trace $=.059 ; \mathrm{F}(20 ; 1224)=.916, p>.05)$ variables are not significant. The age of beginning to use digital game play (Pillai's Trace $=.124 ; \mathrm{F}(20 ; 1224)=$ 1.959, $p<.05$ ) and the type of game (Pillai's Trace $=.042 ; \mathrm{F}(5 ; 303)=2.68, \mathrm{p}<.05)$ ) variables differ substantially. 
When the importance of interactions is studied, although the difference is significant for the age of starting to be subjected to digital game play and the the type of game prefered, It has a subtle effect on explaining $3 \%$ and $4 \%$ of the variants of the scores obtained from the linear component for the digital game effects sub-dimensions, respectively.

One-way ANOVA test (Multivariate ANOVA) results are given in Table 6 to observe the dependent variables contributing to multivariate difference.

Table 6

One-factor ANOVA results for the difference between groups of sub-dimensions of parents' Digital Awareness Level

\begin{tabular}{|c|c|c|c|c|c|c|}
\hline Independent & Dependent & $\mathbf{F}$ & $\mathbf{p}$ & Sd & $\eta^{2}$ & Fark \\
\hline Variable & Variable & & & & & \\
\hline \multirow[t]{6}{*}{ Starting Age } & Entertainment & 2.120 & .078 & \multirow{6}{*}{$4 / 307$} & .027 & - \\
\hline & Learning & .933 & .445 & & .012 & - \\
\hline & Physical & 1.91 & .109 & & .024 & - \\
\hline & Social & 6.078 & 000 & & .073 & Pre-3 years- 4 year old, 5 \\
\hline & & & & & & year old, 6 year and older \\
\hline & Emotional & 1.117 & .349 & & .014 & - \\
\hline \multirow[t]{5}{*}{ Game Type } & Entertainment & 67.964 & $.000 *$ & \multirow{5}{*}{$1 / 307$} & .18 & Traditional-Digital \\
\hline & Learning & 1.013 & .315 & & .003 & - \\
\hline & Physical & 31.856 & $.000^{*}$ & & .094 & Traditional-Digital \\
\hline & Social & 29.320 & $.000 *$ & & .089 & Traditional-Digital \\
\hline & Emotional & 10.762 & $.001 *$ & & .034 & Traditional-Digital \\
\hline
\end{tabular}

When the significance of the difference test is analyzed in Table 6, the age of exposure to digital game play use differs considerably only in the Social sub-dimension (F4 / $307=6.078, p$ $<.05)$. The difference is between pre- 3 years old and 4 years old, 5 years old, 6 years and older. 
The parents of children who were introduced to digital games at the age of three and before $(X=3.16), 4$ years old $(X=2.52), 5$ years old $(X=2.51)$ and 6 years old $(X=2.64)$ It states that its effect is more adverse. When the effect size was analyzed, it was seen that the effect degree $(\mathrm{n} 2=.73)$ was moderate. In other words, parents whose children were introduced to digital games before 3 years of age stated that social effects on their children were higher than other age groups. This difference is of medium importance.

For the game round variable, Fun (F1 / $307=67.964, p<.05)$, Physical $(F 1 / 307=31.856, p$ $<.05)$, Social (F1 / $307=29.320, p<.05)$, and Emotional $(F 1 / 307=10.762, p<.05)$ the difference according to the sub-dimensions is significant. In the comparison made for the entertainment dimension, they stated that the fun effect of digital games is lower than the parents whose children prefer traditional games $(X=3.13)$ than the parents who prefer digital games $(X=3.78)$. The effect degree of this difference $(2=.73)$ is large. $18 \%$ of the fun variable is explained by the game type prefered. For the physical sub-dimension, parents who prefered digital games $(X=2.58)$ stated that the physical effects of digital games were higher than the parents who prefered traditional games $(X=1.99)$, and approximately $9 \%$ of this variable was explained by the game prefered. The situation is the same for the social and emotional subdimensions. The parents who prefered digital games $(X=3.03)$ stated that the negative social effects of digital games were higher than the parents who prefered traditional games $(X=$ 2.45). Likewise, the parents who prefer digital games $(X=2.28)$ stated that the negative emotional effects of digital games are higher than the parents who prefer traditional games $(X$ $=1.91)$. Effect sizes for these variables are .089 and .034 , respectively. The degree of social impact is moderate, while the degree of emotional impact is small.

Parents with 4 or more children $(X=1.71)$ were found to be lower than parents with one child $(X=2.20)$ and two children $(X=2.06)$ in terms of protection from risks. Approximately $6 \%$ of the digital awareness protection from risks dependent variable is explained by the number of children owned. In other words, it can be said that the effect degree of the number of children 
in the house is partially low. Efficient use for the number of children variable (F1 / $307=.091$, $p>.05)$, negative modeling ( $F 1 / 307=2.359, p>.05)$ and digital neglect $(F 1 / 307=2.544, p>$ .05) It has been revealed that there is no significant difference according to the dependent variables.

When the differentiation level of the sub-dimensions for the game type variable is examined, the sub-dimension of being a negative model $(F 3 / 307=2.423, p>.05)$ does not differ significantly. When the variables of protection from risks ( $F 1 / 307=12.677, p<.05$ ), efficient use $(F 1 / 307=56.375, p<.05)$ and Digital Neglect $(F 1 / 307=14.712, p<.05)$, the difference is significant has been seen. In the risk protection variable, it is said that the parents whose children prefer digital games $(X=2.14)$ have higher levels of awareness compared to the parents who prefer traditional games $(X=1.91)$. When the effect size was examined $(n 2=$ .04), it was seen that the effect degree was low. Considering the efficient use, it has been observed that the parents whose children prefer digital games $(X=2.62)$ have higher levels of awareness compared to the parents who prefer traditional games $\left(X^{-}=1.99\right)$. Approximately $16 \%$ of their productive usage levels are explained by the type of games children prefered. It can be said that the type of game prefered has a high effect on the variable of efficient use. A similar result was obtained in the comparison made for the digital negligence variable. Parents whose children prefer digital games $(X=3.65)$ have higher awareness than parents who prefer traditional games $(X=3.99)$. However, the effect degree $(n 2=.05)$ is low.

\section{DISCUSSION \& CONCLUSION}

In a study in Turkey on the digital parenting self-efficacy perception levels of parents, the variables of internet usage experience, income status, profession and education level were examined as independent variables. It was determined that there is no significant difference in digital parenting dimensions according to the parental role (Yaman et al., 2019). As a result of this research, it was concluded that the digital awareness levels of the parents did not differ significantly according to their gender, the time they spent in digital media and the age of their 
children to start playing digital games. It is seen that the digital awareness levels of the parents differ significantly according to the number of children they have and the variables of the type of game their children prefer to play. The digital awareness levels of parents differ only in the risk protection sub-dimension according to the number of children parents have. Parents with four or more children were found to be lower in protection from risks than parents with one or two children. Approximately $6 \%$ of the parents' digital awareness protection from risks dependent variable is explained by the number of children parents have. It is concluded that the number of children in the house has an effect, even if it is low. It can be seen that children generally adopt similar approaches to parents in terms of internet use (Terkan \& Taylan, 2010). As a result of a study conducted with mothers, it was understood that parents did not want to let their children use televisions, tablets and smart phones. Despite this, it has been determined that even the most determined ones cannot stand the wishes of their children and make them use it from time to time (Cengiz Saltuk \& Erciyes, 2020). In order for parents with many children to protect their children from risks, it may be suggested that they share responsibilities regarding their children with other parents or family members, if possible. In addition, it may be suggested to plan for their children not to be exposed to technology at the same time, in such a planning, while the parent tries to protect the child exposed to technology from risks, other children may encourage other children to play traditional children's games or to engage in activities.

The digital awareness levels of parents differ significantly in the sub-dimensions of protection from risks, efficient use and digital neglect according to the independent variable of the type of game their children prefer to play. Parental digital awareness levels were found to be higher in all three sub-dimensions, compared to parents whose children prefer to play digital games, and parents whose children prefer to play traditional games. While the effect of the game type preferred by children was low in the protection from risks and digital neglect sub-dimensions, it was found to have a high effect in the efficient use sub-dimension. It can be 
said that parents make use of digital games in order to contribute to children's learning activities. Positive behaviors in children are reinforced with educational digital games (Prot et al., 2014), children's language skills, mental skills, and memory development are supported (Schacter \& Jo, 2016). When educational digital games are used consciously, they encourage children to think and learn (Griffiths, 2003). However, games have started to pose a risk as a threat to children due to the fast-growing game industry (Taylan et al., 2017). At the same time, in a study conducted by Mustafaoğlu and Yasacı (2018), digital games have been associated with game addiction, anxiety disorder, aggression, depression and mental problems such as social disorders. Parents who prefer their children to play digital games may be advised to ensure that their children contribute to digital learning activities, while at the same time, their children play the digital games they play first, and then to their children, so that they can protect them without neglecting them. As the child often plays digital games alone has negative physical and social impacts (Z. Hazar et al., 2017), parents will be able to protect their child from digital risks, if the child can achieve the same benefits as traditional children's games, parents can they can be directed to play the game.

It was concluded that the levels of parental awareness regarding the effects of digital games on their children at early ages did not differ according to the gender of the parents, the number of children they had and the time they spent in digital media. Parental awareness levels regarding the effects of digital games on their children at an early age show a significant difference according to the independent variables of the age when children start playing digital games and the type of game their children prefer to play. Parental awareness levels about the effects of digital games on their children at early ages differ significantly only in the social subdimension according to the age when children start playing digital games. It has been concluded that the parents of children who started playing digital games at the age of three and before stated that the effect of digital games on their children was very negative compared to the parents of children who started playing digital games at the age of $4,5,6$ and 
later, and this difference is also of moderate importance. . The age of starting the game in the digital environment and having the first phone (starting to use), which has been examined as the precursor of game and phone addiction, has an important role in both addictions (Bülbül \& Tunç, 2018). In a study, it was found that children between the ages of 0-6 met with television between the ages of 12 months, mobile phones between 12-23 months, and computers and tablets between 24-35 months (Aral \& Doğan Keskin, 2018). They emphasized that age and developmental periods should be taken into consideration in order to determine the usage characteristics and risks (cited in Manap \& Durmuş, 2020). As the effect of the digital world, children spend most of their time with digital games (Söğüt, 2020), when the child starts to socialize with his environment, digital exposure to games has a negative effect on children in the early period. When the relevant literature is examined, it is seen that children take their social environment as a model in the use of technology (Toran et al., 2016), but that children think they socialize while playing digital games and experience emotional inadequacies (Ataman Yengin, 2019). Parents stated that their children allocate a significant part of their time to digital games and that the age of starting digital games is down to 4 years old (Sögüt, 2020). For this reason, it can be recommended that parents provide rich learning environments that appeal to all their senses, especially in infancy and early childhood, and spend quality time with their children without leaving their children on digital game screens.

Parental awareness levels regarding the effects of digital games on their children at an early age differ significantly according to the independent variable of the type of game that their children prefer to play in the fun, physical, social and emotional sub-dimensions. It has been observed that the entertaining, physical, social and emotional effects of digital games are lower than the parents who prefer the traditional game type for their children compared to the parents who prefer digital games. The degree of entertainment effect is high, the degree of social influence is medium, and the degree of physical and emotional effects is low. It is thought that as a result of the behavior that children acquire through social learning, digital 
device increases the risk of addiction (Burger, 2006, cited in Manap \& Durmuş, 2020). Due to the joy and pleasure of playing digital games, children prefer digital games more (Aydoğdu Karaaslan, 2015). Consistent with this result, this study concluded that parents' children have more fun while playing digital games than traditional games. Although children change their world and have functions such as leisure time and stress relief, the violence they contain is perceived as a normal situation by children (Aydoğdu Karaaslan, 2015). The fact that children often play digital games alone has negative physical and social effects (Z. Hazar et al., 2017). Digital games that are not suitable for the age of children worry parents (Torun et al., 2013). In this study, it was concluded that the digital games of parents negatively affect the social, physical and emotional development of their children. Of these effects, the degree of social impact is very high. In this context, it can be suggested that parents should play traditional children's games, which they think their children have more fun, in a controlled manner by supporting their children with time constraints and a suitable playing environment in order for their children to socialize and to ensure healthy emotional and physical development.

\section{Interest Statement}

The author (s) have not declared any potential conflicts of interest regarding the research, authorship and / or publication of this article.

\section{Support / Financing Information}

The author (s) did not receive any financial support for research, authorship, and / or publication of this article.

\section{Ethical Committee Decision}

Ethical permission was obtained from the 2021/4-22 Inonu University Social and Humanities Scientific Research Ethical Committee for this research.

\section{References}


Aksoy, A. B., \& Dere Çiftçi, H. (2020). Erken Çocukuk Döneminde Oyun. In PEGEM Akademi. PEGEM Akademi, Ankara.

Aktaş Arnas, Y. (2017). Oyun, Öğrenme ve Deneyimin Birleşimi: Çocuk Müzeleri. Yaratıcı Drama Dergisi, 12(2), 17-30. https://doi.org/10.21612/yader.2017.010

Alpar. R. (2003) Uygulamalı çok değişkenli istatistiksel yöntemlere giriş 1 (ikinci baskı). Ankara: Nobel Yayınları.

Allen, P., \& Bennett, K. (2008). SPSS for the Health \& Behavioural Sciences. (1st ed.) Thomson.

Aral, N., \& Doğan Keskin, A. (2018). Ebeveyn bakış açısıyla 0-6 yaş döneminde teknolojik alet kullanımının incelenmesi. Addicta: The Turkish Journal on Addictions, 5(2), 317-348.

Ataman Yengin, D. (2019). Dijital Oyun Bağımlılığı. In G. H. Karadağ (Ed.), Dijital Hastalıklar (p. 124). Der Yayınları, İstanbul.

Aydoğdu Karaaslan, i. (2015). Dijital oyunlar ve Dijital Şiddet Farkındalığı: Ebeveyn ve Çocuklar Üzerinde Yapılan Karşılaştırmalı Bir Analiz. Uluslararası Sosyal Araştırmalar Dergisi, 8(36), 806-818.

http://www.sosyalarastirmalar.com/cilt8/sayi36_pdf/7isletme_iktisat_iletisim_kamu/ay dogdukaraaslan_ilknur.pdf

Balaban Dağal, A., \& Bayindir, D. (2019). Erken Yaşlarda Dijital Oyunların Etkileri Ölçeği'nin Geçerlik ve Güvenirlik Çalışması. Pegem Egitim ve Ogretim Dergisi, 9(4), 979-1000. https://doi.org/10.14527/pegegog.2019.031

Başaran Özdemir, F., \& Babacan, T. (2011). Iletişim, Teknoloji ve Toplum Ilişkisine Dair Temel Yaklaşımlar. https://acikders.tuba.gov.tr/course/view.php?id=97

Başol, G. (2008). Bilimsel araştırma süreci ve yöntem. Kılıç, O., \& Cinoğlu, M. (Editörler). Bilimsel araştırma yöntemleri İçinde 113-143. İstanbul: Lisans Yayıncılık.

Bülbül, H., \& Tunç, T. (2018). Telefon Ve Oyun Bağımlıı̆̆ı: Ölçek İncelemesi, Başlama Yaşı Ve Başarıyla İlişkisi. Süleyman Demirel Üniversitesi Vizyoner Dergisi, 9(21), 1-13.

Cengiz Saltuk, M., \& Erciyes, C. (2020). Okul Öncesi Çocuklarda Teknoloji Kullanımına İlişkin Ebeveyn Tutumlarına Dair Bir Çlışma. Yeni Medya Elektronik Dergi, 4(2), 106-120. https://doi.org/10.17932/iau.ejnm.25480200.2020.4/2.106-120

Cohen J. (1988). Statistical Power Analysis for the Behavioral Sciences. New York, NY: Routledge Academic

Cortina, J. M. (1993). What is coefficient alpha? An examination of theory and applications. Journal of Applied Psychology, 78(1), 98-104. https://doi.org/10.1037/00219010.78.1.98

De Maesschalck, R., Jouan-Rimbaud, D., \& Massart, D. L. (2000). The Mahalanobis distance. Chemometrics and Intelligent Laboratory Systems, 50(1), 1-18. https://doi.org/10.1016/S0169-7439(99)00047-7

Erboy, E., \& Akar Vural, R. (2010). Ilköğretim 4. ve 5. Sınıf Öğrencilerinin Bilgisayar Oyun Bağımlıı̆ı̆ını Etkileyen Faktörler. Ege Eğitim Dergisi, 11(1), 39-58.

Field, A. (2009). Discovering statics using SPSS. London: SAGE.

Genç Çopur, H., Dağlıoğlu, E., \& Dağlı, H. (2020). Google Play Store ve Apple Store'daki Dijital oyunların Matematik Eğitimi Standartları ve Çocuğa Uygunluğu Açısından İncelenmesi. TURAN-SAM Uluslararası Bilimsel Hakemli Dergisi, 12(47), 8041.

Griffiths, M. (2002). The Educational Benefits of Videogames. Education and Health, 20(3), 4751. http://www.sheu.org.uk/pubs/eh203mg.pdf

Griffiths, M. (2003). Videogames: Advice for Parents and Teachers. Education and Health, 21(3), 48-49.

Hazar, M., Altun, M., \& Hazar, Z. (2016). 6-14 Yaş Çocukların Dijital Oyun Oynamalarına İlişkin Ebeveyn Görüşleri (Nitel Bir Araştırma). Uluslararası Hakemli iletişim ve Edebiyat Araştırmaları Dergisi, 12, 40-67. https://doi.org/10.17361/uhive.20161222013 
Hazar, Z., \& Hazar, M. (2017). Çocuklar İçin Dijital Oyun Bağımlılı̆̆ Ölçeği. Journal of Human Sciences, 14(1), 203-216. https://doi.org/10.14687/jhs.v14i1.4387

Hazar, Z., Tekkurşun Demir, G., \& Dalkiran, H. (2017). Ortaokul Öğrencilerinin Geleneksel Oyun ve Dijital Oyun Algılarının Incelenmesi: Karşılaştırmalı Metafor Çalışması. Spormetre, 15(4), 179-190.

Huberty, C. J., \& Morris, J. D. (1989). Multivariate analysis versus multiple univariate analyses. Psychological Bulletin, 105(2), 302-308. https://doi.org/10.1037/0033-2909.105.2.302

Işıkoğlu Erdoğan, N. (2019). Dijital Oyun Popüler mi? Ebeveynlerin Çocukları İçin Oyun Tercihlerinin İncelenmesi. Pamukkale University Journal of Education, 46, 1-17. https://doi.org/10.9779/pauefd.446654

Köklü, N., Büyüköztürk, Ş., \& Bökeoğlu, Ö. Ç. (2007). Sosyal bilimler için İstatistik. (Geliştirilmiş 2.Baskı) Ankara: PegemA Yayıncılık.

Manap, A., \& Durmuş, E. (2020). Dijital Ebeveynlik Farkındalık Ölçeğinin Geliştirilmesí. Inönü Üniversitesi Eğitim Fakültesi Dergisi, 21(2), 978-993.

https://doi.org/10.17679/inuefd.711101

Mustafaoglu, R., \& Yasacı, Z. (2018). Dijital Oyun Oynamanın Çocukların Ruhsal ve Fiziksel Sağlığı Üzerine Olumsuz Etkileri. Bağımlıık Dergisi, 19(3), 51-58.

Olson, C. L. 1974. Comparative Robustness of Six Tests in Multivariate Analysis of Variance. Journal of the American Statistical Association, 69:348, 894-908.

Orman, N. K., \& Arıcak, O. T. (2019). Aşırı Dijital Oyun Oynama Davranışında Anne Tutumu Ve Benlik Kontrolünün Etkisi. Cyprus Turkish Journal of Psychiatry and Psychology, 1(1), 4042. https://doi.org/10.35365/ctjpp.19.special1.11

Pallant, J. (2005). Spss survival manual: a step by step guide to data analysis using spss for windows. Australia: Australian Copyright.

Prot, S., Anderson, C. A., Gentile, D. A., Brown, S. C., \& Swing, E. L. (2014). The Positive and Negative Effects of Video Games. In A. B. Jordan \& D. Romer (Eds.), Media and the WellBeing of Children and Adolescents (pp. 109-128). http://www.raisesmartkid.com/3-to-6years-old/4-articles/34-the-good-and-bad-effects-of-video-games

Schacter, J., \& Jo, B. (2016). Improving low-income preschoolers mathematics achievement with Math Shelf, a preschool tablet computer curriculum. Computers in Human Behavior, 55, 223-229. https://doi.org/10.1016/j.chb.2015.09.013

Seçer, i. (2015). SPSS ve Lisrel ile pratik veri analizi: analiz ve raporlaştırma. Ankara: Anı.

Sezen, D. (2011). Katılımcı Kültürün Oluşumunda Yeni Medya Okuryazarlığı: ABD ve Türkiye Örnekleri. Doktora Tezi, İstabul Üniversitesi, Sosyal Blimler Enstitüsü, İstanbul.

Söğüt, F. (2020). Dijital Ebeveynlerin Dijital Oyunlar ve Şiddet ilişskisine Yönelik Algıları. Iletişim Kuram ve Araştırma Dergisi, 51, 79-100.

Tabachnick, B.G., \& Fidell, L.S. (2007). Using multivariate statistics. Boston, Pearson Education, Inc.

Taylan, H. H., Kara, H. Z., \& Durğun, A. (2017). Ortaokul ve Lise Öğrencilerinin Bilgisayar Oyunu Oynama Alışkanlıkları ve Oyun Tercihleri Üzerine Bir Araştırma. PESA Uluslararası Sosyal Araştırmalar Dergisi, 3(1), 78-87.

Terkan, N., \& Taylan, A. (2010). Internet ve Çocuların Korunması: Ebeveyn Kontrolü. Uluslararası Yeni Iletişim Ortamları ve Etkileşim Konferansı, 338-342.

Toran, M., Ulusoy, Z., Aydın, B., Deveci, T., \& Akbulut, A. (2016). Çocukların Dijital Oyun Kullanımına llişkin Annelerin Görüşlerinin Değerlendirilmesi. Kastamonu Eğitim Dergisi, 5. http://79.123.169.199/ojs/index.php/Kefdergi

Torun, F., Akçay, A., \& Çoklar, A. N. (2013). Bilgisayar Oyunlarının Ortaokul Öğrencilerinin Akademik Davranış ve Sosyal Yaşam Üzerine Etkilerinin İncelenmesi. Karaelmas Journal of Educational Sciences, 1(3), 25-35. 
TÜik. (2020). Hanehalkı Bilişim Teknolojileri (BT) Kullanım Araştırması.

https://data.tuik.gov.tr/Bulten/Index?p=Hanehalki-Bilisim-Teknolojileri-(BT)-KullanimArastirmasi-2020-33679

Yalçın Irmak, A., \& Erdoğan, S. (2016). Ergen ve Genç Erişkinlerde Dijital Oyun Bağımlııı̆ı: Güncel Bir Bakış. Turk Psikiyatri Dergisi, 27(2), 1-10. https://doi.org/10.5080/u13407

Yaman, F., Dönmez, O., Kabakçı Yurdakul, I., \& Odabaşı, F. (n.d.). Dijital Dünyanın Ailesi İnternetik Aile. In Eğitim Teknolojileri Okumaları.

Yaman, F., Dönmez, O., Akbulut, Y., Yurdakul, I. K., Çoklar, A. N., \& Guyer, T. (2019). Ebeveynlerin dijital ebeveynlik yeterliklerinin çeşitli demografik değişkenler açısından incelenmesi. Eğitim ve Bilim, 44(199).

Yee, N. (2006). Motivations for Play in Online Games. Cyberpsychology and Behavior, 9(6), 772-775. https://doi.org/10.1089/cpb.2006.9.772

Yiğit, E., \& Günüç, S. (2020). Çocukların Dijital Oyun Bağımlılığına Göre Aile Profillerinin Belirlenmesi. YYÜ Eğitim Fakültesi Dergisi (YYU, 17(1), 144-174. https://doi.org/10.33711/yyuefd.691498

Zeybekoğlu Akbaş, Ö., \& Dursun, C. (2020). Teknolojinin Aileye Etkisi: Değişen Ailenin Dijital Ebeveyn ve Çocukları. Turkish Studies-Social Sciences, 15(4), 2245-2265. https://doi.org/10.29228/turkishstudies.43395

İletişim/Correspondence

Dr. Öğr. Üyesi Sümeyra AKKAYA sumeyra.akkaya@inonu.edu.tr

Zeynep TAN

zeyyneptann@gmail.com

Dr. Öğr. Üyesi Metin KAPIDERE metin.kapidere@inonu.edu.tr

Dr. Öğr. Üyesi Seda ŞAHiN seda.sahin@inonu.edu.tr 